\title{
SOLIDS WITH CRACKS AND PORES OF VARIOUS SHAPES: PROPER PARAMETERS OF DEFECT DENSITY, ANISOTROPY AND EXTRACTION OF INFORMATION ON DAMAGE FROM WAVESPEED PATTERNS
}

\author{
DOE Grant DE-FG02-97ER14794 \\ Principal Investigator: Mark Kachanov
}

\section{Final report}

The research under the grant was focused on the micromechanics of with multiple defects of diverse shapes. Within this general area, the problems addressed were quite diverse:

- Mechanics of materials with multiple defects

- Mechanics of electro-elastic materials

- Plasticity of porous materials.

The results have been presented at a number of conferences and seminars:

\section{Conferences}

ASME-SES-ASCE Meeting, Evanston, 1997, Il (two lectures)

Symposium on Continuum Models of Discrete Systems, Turkey 1998 (invited lecture)

International Conference on Computer Methods in Composites, Montreal, Canada, 1998

Symposium on Energy Sciences, Argonne, Illinois, 1999

European Conference on Solid Mechanics, Germany, 1999

Meeting of the American Ceramic Society, St.Louis, 2000, (invited lecture)

Workshop on Acoustic Materials, Penn State U., 2000

NATO Workshop on Physical Aspects of Fracture, France, 2000 (two invited lectures)

Materials Research Society Meeting, Boston, 2000, to be given (invited lecture)

\section{Seminars and invited lectures}

Harvard U (1997); Rensselaer Polytechnic Institute (1997); Dartmouth College (1997); Ecole Normale Superieure, France (1997,1999); Aberdeen Proving Grounds (1997); Swiss Federal Institute of Technology (1998); Penn State U (1998); Technical U of Delft, Netherlands (1998); U of Texas at Austin (1998); Ecole Polytechnique, France (1999); United Technologies Res Center (1999); U of Bochum, Germany (1999); U of Bern, Switzerland (1999); U of California at Santa-Barbara (1999); U of Dresden, Germany (1999), General Electric R\&D Center (2000); U of Connecticut (2000); U of Hannover, Germany (2000); NIST (2000); CALTECH (2000); Siemens-Westinghouse R\&D Center, Munich, Germany, 2000; Swiss Society for Testing of Materials (EMPA), 2000; Naval Research Labs (2000).

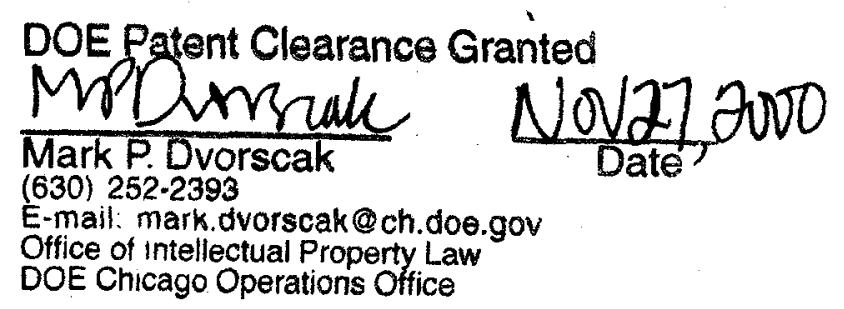




\section{DISCLAIMER}

This report was prepared as an account of work sponsored by an agency of the United States Government. Neither the United States Government nor any agency thereof, nor any of their employees, make any warranty, express or implied, or assumes any legal liability or responsibility for the accuracy, completeness, or usefulness of any information, apparatus, product, or process disclosed, or represents that its use would not infringe privately owned rights. Reference herein to any specific commercial product, process, or service by trade name, trademark, manufacturer, or otherwise does not necessarily constitute or imply its endorsement, recommendation, or favoring by the United States Government or any agency thereof. The views and opinions of authors expressed herein do not necessarily state or reflect those of the United States Government or any agency thereof. 


\section{DISCLAIMER}

Portions of this document may be illegible in electronic image products. Images are produced from the best available original document. 


\section{Publications under the Grant}

1. E.Karapetian and M.Kachanov "Green's Functions for a Transversely Isotropic Space containing a Circular Crack", Acta Mechanica, v.126, pp. 169-187, 1998.

2. B. Shafiro and M.Kachanov "Solids with Non-Spherical Cavities: Cavity Compliances and the Overall Anisotropy", Journal of the Mechanics and Physics of Solids, v.46(2), pp 1-21, 1998.

3. B.Nuller, E.Karapetian and M.Kachanov "On the Stress Intensity Factor for the Elliptical Crack", International Journal of Fracture, v. 92, no.2, pp. L17-20, 1998.

4. E.Karapetian and M.Kachanov "On Calculation of SIFs for Circular and Moderately Non-Circular Cracks", International Journal of Fracture, v. 92, no. 2, pp. L21-26, 1998.

5. I. Tsukrov and M.Kachanov "Anisotropic Material with Arbitrarily Oriented Cracks and Elliptical Holes: Effective Elastic Properties", International Journal of Fracture v 92(1) pp L3-8, 1998

6. I.Sevostianov and M.Kachanov "Microstructure of the Cortical Bones and Their Effective Elastic Properties", International Journal of Fracture, v. 92, no.1, pp. L9-14, 1998.

7. I.Sevostianov and M.Kachanov "Compliance Tensors of Ellipsoidal Inclusions", International Journal of Fracture, v.96, no.1, L3-7, 1999.

9. M.Kachanov "Solids with Cracks and Non-Spherical Cavities: Proper Parameters of Defect Density and Effective Elastic Properties", International Journal of Fracture, v.97, pp. 1-32, 1999.

10. E.Karapetian, I.Sevostianov and M.Kachanov "Point Force and Point Electric Charge in Piezoelecric Transversely Isotropic Solids", Philosophical Magazine-B, v.80 (3), pp. 331-359, 2000.

11. E.Karapetian, I.Sevostianov and M.Kachanov "Penny-Shaped and Half-Plane Cracks in the Piezoelectric Transversely Isotropic Solid, Archive of Applied Mechanics, v. 70 (1-3), pp. 201-229, 2000.

12. L.Gorbatikh and M.Kachanov "Construction of the Displacement and Stress Fields in a Plane with Multiple Cracks”, Engineering Fracture Mechanics, v. 60, pp. 53-65, 2000.

13. I.Sevostianov and M.Kachanov "On the yield condition for anisotropic porous materials", Materials Science and Engineering (under review).

14. I. Sevostianov "Green's tensor for three-dimensional orthotropic material", Proc. Roy. Soc (under review) 
.15. V.Levin, I.Sevostianov and M.Kachanov, On modeling and design of piezocomposites with prescribed properties, Mechanics of Materials (under review). 